\title{
Criminal Imprisonment for Criminal Offenses Insults the President after State Court Decision Number: 013-022 / PUU-IV / 2006 (Study on State Court Blora Decision Number: 47 / PID. SUS / 2017 / PN.Blora)
}

\begin{abstract}
Yustisi Yudhasmara ${ }^{1}$, Umar Ma'ruf $^{2}$ and Sri Endah Wahyuningsih ${ }^{3}$
Abstract. The purpose of this study was to analyzing the impact of the juridical the removal of article criminal offense insult the president by the State Court Decision Number 013-022 / PUU-IV / 2006 as well as the consideration of Judges State Court of Blora in Decision No. 47 / Pid.Sus / 2017 / PN.Blora, as well as to analyze the existence of article insult the President in future be associated with the rise of social media.

This study uses empirical juridical approach, the research specification descriptive. The data used in this study are primary data obtained from field studies that were analyzed qualitatively using the theory of criminal prosecution and criminal punishment, the theory of law enforcement and crime prevention theory. Then for secondary data obtained from ingredients documents or library materials.

The final conclusion is that: The Impact of juridical when articles of insult against the President revoked, can damage the system in the inclusion of clauses concerning acts humiliation as a whole and also the revocation of article of insult against the President and Vice President do not have binding legal force so that their legal vacuum post the decision of the judge in the consideration while deciding the case No. 47 / Pid.Sus / 2017 / PN.Blora according to the indictment from the prosecutor. Because of Article 193 paragraph (1) of Act No. 8 of 1981 on Criminal Proceedings ( "Criminal Code") Existence of article insult the president in the future, should come up again all the rules, could reach the criminal insult the president with any form of media used

Keywords: Offense; insult the president; the State Court; RKUHP.
\end{abstract}

\section{Introduction}

Many cases of insult or defamation is now widespread as the presence of the media, both print and electronic media ${ }^{4}$, Cases like an insult to the President in 2006 conducted by Eggy Sudjana to President Susilo Bambang Yudhoyono, eventually resulting in the State Court ruling number: 013-022 / PUU-IV / 2006. Earlier on January 3, 2006 Eggy Sudjana committed the crime of defamation against the President. Against such cases eventually Eggy Sudjana filed a judicial review to the State Court by the Article 134, 136 buses and 137 of the Criminal Code that are considered contrary to the Act of 1945 Constitution, generally among student activists and politicians, particularly in the New Order era, the use of articles 134, 136 bis and 137 Penal Code is seen as a form of restraint or political repression against them.

\footnotetext{
${ }^{1}$ Student of Master of Law, Universitas Islam Sultan Agung Semarang and Bussiness Staff, email: yyudhasmara@gmail.com

${ }^{2}$ Lecturer of Master of Law, Sultan Agung Islamic University (UNISSULA), Semarang

${ }^{3}$ Lecturer of Master of Law, Sultan Agung Islamic University (UNISSULA), Semarang

4 https://handarsubhandi.blogspot.com/2015/08/upayapenanggulangankejahatan (accessed on February 8th, 2020 at 21:05 pm)
} 
The use of these chapters is seen as a way of facing the government, controlling and off criticisms of the behavior and policies of President ${ }^{5}$, After a few years have passed since the decision of the State Court Number: 013-022 / PUU-IV / 2006. The current government led by President Jokowi and been several cases of defamation against the President Jokowi as leader of the country. One such case is the alleged author Bambang Tri Mulyono on Jokowi undercover, trace the identity of the forger. In addition to writing a book whose contents charged libel to President Jokowi, within the month of November 2016 had written words intended to cause hatred or hostility based SARA ${ }^{6}$, In such cases the judges finally ruled on the number: 47 / Pid.Sus / 2017 / PA.Bla with criminal against the defendant Bambang Tri Mulyono Bin (Alm) Suradi with imprisonment for four (4) years provided for in Article 28 paragraph (2) Jo. Article $45 \mathrm{~A}$ (2) of the Constitution of the Republic of Indonesia No. 19 of 2016 on the Amendment Law of the Republic Indonesia No. 11 of 2008 on Information and Transactions electronic Jo. Article 64 paragraph (1) of the Criminal Justice Act.

After the revocation of Article 134, Article 136 bis, and Article 137 of the Criminal Code, the Court Constitution contained in its decision number: 013-022 / PUU-IV / 2006, and the notes from the State Court which put Article 207 as to a complaint. Law enforcement officers can only process a violation of Article 207 after complaints from the authorities, because of the limitations that FINALLY each case after the Court's decision Constitution, have limitations in bondage punishment, as in the case of State Court of Blora case number: 47 / Pid.Sus / 2017 / PN.Blora, judges finally decide with the Law of the Republic of Indonesia No. 19 of 2016 on the Amendment Law of the Republic of Indonesia No. 11 of 2008 on Information and electronic transactions.

Based on the above description, it can be proposed formulation of the problem: What is the impact juridical ofthe removal of article criminal offense insult the president by the State Court Decision Number 013-022 / PUU-IV / 2006as well as Judge of State Court Consideration Blora in Decision No. 47 / Pid.Sus / 2017 / PN.Blora?; How does the existence of article insult the future president, was associated with the rise of social media?

\section{Research method}

This study uses empirical juridical approach, the research specification descriptive. The data used in this study are primary data obtained from field studies that were analyzed qualitatively using the theory of criminal prosecution and criminal punishment, the theory of law enforcement and crime prevention theory. Then for secondary data obtained from ingredients documents or library materials.

\section{Results And Discussion}

\footnotetext{
${ }^{5}$ Irawan Santoso and Togi Simanjuntak, 1998, Politik Pembebasan Tapol, Yayasan Lembaga Bantuan Hukum Indonesia, Jakarta, p.107

6 http://pn-blora.go.id/main/index.php/berita/berita-terkini/937-vonis-3-tahun-penjara-untuk-penulisbuku-jokowi-undercover, Accessed Sunday, September 15, 2019 at 18:00 pm
} 


\subsection{The Impact Of The Removal Of Article Juridical Criminal Act Of Insult The President By The State Court Decision Number 013-022 / PUU-IV / 2006 As Well As Consideration Of State Court Of Blora In Decision Number: 47 / Pid.Sus / 2017 / PN.Blora.}

The criminal act is usually equated with the offense, which is derived from the Latin word delictum said. Offense listed in Indonesian Dictionary as follows: "The offense is an act punishable as a violation of the law criminal offense ${ }^{7}$. Explain Article 310 of the Criminal Code that, "insult" is attacking the honor and reputation of a person, who was attacked is usually embarrassed the honor of being attacked here only about the honor of the good name and not honor in the field sexual, honor that can be stained as offended members of his cock in the environment lust sex ${ }^{8}$.

The President is a state institution that holds sway in the field of the executive. However, the 1945 Constitution also stipulates the provision that the President also perform functions related to the legislative or judicial matters. Under the provisions of the Constitution, the President must be citizens of Indonesia since birth and never received another citizenship ${ }^{9}$.

Criminal acts of insult against the president or vice president is set in Chapter II of Book II of the Criminal Code on crimes against the dignity of the President and Vice President. Originally this chapter consists of 11 chapters, but under Article VIII of Act No. 1 In 1946, 6 article removed for governing the royal family, which in Indonesia is not there. Thus there are only five (5) articles, namely Article 131, Article 134, Article 136 bis, Section 137 and Section $139^{10}$. According Cleiren, said there were insults (belediging; slander; defamation), when the honor (eer; honor) or good name (goede naam; reputation) person is attacked (aanggerand; impugns). While the notion of "honor" refers to "respect" is the right person as a human being. Furthermore, the notion of "good name" refers to "reducing a person's dignity in the eyes of others". Regarding what constitutes "insulting nature" (beledigend character) depends on the norms of society at that time ${ }^{11}$.

Regarding insult that can be addressed to any person as stipulated in Article 310 Article 321 of the Criminal Code there are five qualifying as an insult, namely: rail (smaad) rejects both orally and / or in writing; defamatory (laster); mild insult (eenvoudige belediging); pitted be defamatory (lasterlijke aanklacht); and the allegation is defamatory (lasterlijke verdachtmaking). The fifth form of insult to a

\footnotetext{
${ }^{7}$ Department of Education, 1989, Kamus Besar Bahasa Indonesia, print. 2nd, Balai Pustaka, Jakarta, p. 219

${ }^{8}$ R. Susilo. 1991, Kitab Undang-Undang Hukum Pidana (KUHP) Serta Komentar-Komentarnya Lengkap Pasal Demi Pasal, Politeia, Bogor, p.3

${ }^{9}$ Hidayat Nur Wahid, Lembaga Negara Berdasarkan Undang - Undang Dasar Negara Republik Indonesia Tahun 1945, article, Legality 2006, taken from http://www.legalitas.org/?q=node/75, padatanggal accessed October 16, 2019, 16:00 pm

${ }^{10}$ Wirjono prodjodikoro 2002, Tindak-Tindak Pidana Tertentu Di Indonesia, Refika Aditama, Bandung: p.207

${ }^{11}$ Mardjono Reksodiputro, 2009, Tentang Penghinaan Terhadap Presiden Dan Wakil presiden Serta Kebebasan Memperoleh Informasi, dalam Buku Menyelaraskan Pembaruan Hukum, Komisi Hukum Nasional, Jakarta p. 57
} 
complaint it is explicitly stated in Article 319 of the Criminal Code ${ }^{12}$. As several articles in the penal code governing insult to the president, namely:

- Article 134 of the Criminal Code reads "deliberate insult against the President or the Vice President be punished with imprisonment for a duration of six years or a fine of up to four thousand five hundred rupiah";

- Article 136 bis of the Penal Code states that "the words of insult on purpose in Article 134 contains also acts described in Article 315, if it is done if despised not present, that is good in public, but in front of more than four people or in front of other people, who are present with no volition and touched his heart, will, by deeds, or orally or in writing;

- Article 137 of the Criminal Code, Article contains two (2) points verse, namely: (1) Any person who, or paste text or images whose content insulting the President or Vice President with the intention that the contents that insult was known by many or more unknown by the crowd, was sentenced to jail forever one year and four months or a fine of up to four thousand five hundred rupiah. (2) If mistake committed the crime in the post and at the time of committing the crime not to mention the last two years after the first fixed penalty because it was too similar crimes, then he can be dismissed from office.

Now an insult to the Head of State of the Republic of Indonesia or its representative, it is still important just from the history of criminal law alone. Due by the State Court in its meeting of December 6, 2006 by decision No.013-022 / PUU-IV / 2006, the verdict states that the norm of crimeArticle 134.136 buses and 137 "not legally binding ${ }^{13}$. impact Juridical decision Number 013-022 / PUU-IV / 2006 with the revocation of the article on defamation against the President or Vice-President have considerable consequences. Insult to the dignity of the President and Vice President is not regarded as a crime. As if the office of President and Vice-President was there but without dignity attached to it. When an act of insulting the President, the only channel that can be used to protect the article the President or the Vice President as a victim of insult is Article 310 paragraph (1) of the Criminal Code, Article 310 paragraph (2) of the Criminal Code, and section 315 of the Criminal Code. Article - This article is basically used to protect ordinary people from the crime of insult. According to the authors, this condition is not in accordance with the systems and patterns used in the Criminal Code. In the Criminal Code adheres to the gradation value, in this case the President or Vice President has a higher status than ordinary people. It is not fair when the President or Vice President of generalized with ordinary people. The President or VicePresident should be given greater protection than ordinary people. This is related to the status of the President or Vice President as head of state, the symbol of state and heads of state. Seen from the perspective of constitutional law in the Republic with a presidential state system of the dignity of the state is inherent to a President or Vice President. The President or Vice-President should be given greater protection than ordinary people. This is related to the status of the President or Vice President as head of state, the symbol of state and heads of state. Seen from the perspective of

\footnotetext{
${ }^{12}$ Eddy OS Hiariej, 2014, Prinsip-Prinsip Hukum Pidana, Cahaya Atma Pustaka, Yogyakarta, p.111

${ }^{13}$ Adami Chazawi, 2016, Hukum Pidana Positif Penghinaan (Edisi Revisi), print. 2, Media Nusantara Creative, Malang, p.162
} 
constitutional law in the Republic with a presidential state system of the dignity of the state is inherent to a President or Vice President. The President or Vice-President should be given greater protection than ordinary people. This is related to the status of the President or Vice President as head of state, the symbol of state and heads of state. Seen from the perspective of constitutional law in the Republic with a presidential state system of the dignity of the state is inherent to a President or Vice President.

Other juridical impact, as a result of the State Court Decision Number 013-022 / PUUIV / 2006 which states Article 134, Article 136 bis, and Article 137 of the Criminal Justice Act regarding insults against the President and Vice President do not have binding legal force so their legal vacuum after the verdict even though it does not require further legislation or changes. As president of the criminal offense in Indonesia, which has revoked the State Court, causing motion in the sentencing law enforcement chapter by chapter is limited. Because the President as Head of State equated with a public position. While the constitution of electronic letter of president has an important function in a country, and must be maintained honor.

Insult the President shall cause a great impact in the community as an insult the president will also lead to apathy to the government for other communities who believe the sentences the insult, and it is motivated by a factor of Culture such as lack of literacy, poor reading culture, and preferences in various gossip story ${ }^{14}$.

One form of a legal void of juridical effects of the decision State Court Number 013-022 / PUU-IV / 2006, as in the case in the State Court Blora No. 47 / PID. SUS / 2017 / PN.Blora act in case of an insult to the president through the book Jokowi Undorcover made by the defendant Bambang Tri Mulyono Bin (Alm) Suradi. In the State Court of Blora, a judge decide Bambang Tri Mulyono Bin (Alm) Suradi threatened with in article 28 paragraph (2) Jo. Article 45 A (2) of the Constitution of Republic of Indonesia number 19 Of 2016 on the Amendment of the Act No. 11 Of 2008 on Information and Electronic Transactions Jo. Article 64 paragraph (1) of the Criminal Justice Act. The judges decide by just looking at the facts through Social Media facebook Bambang Tri Mulyono only, while Jokowi Undercover shaped guide hardcopy, can not serve as the basis for sentencing as well. The question now, if in a few years the criminal act insult the president but instead of electronic media or social media, What legal basis should be used by the judge in deciding the case, while the ius curia novit principle, the judge deemed to know all the laws that the court did not may refuse to investigate and adjudicate the case. This is confirmed in Article 10 of Act No. 48 of 2009 on Judicial Power, as follows the judge deemed to know all the laws that the court may not refuse to investigate and adjudicate the case. This is confirmed in Article 10 of Act No. 48 of 2009 on Judicial Power, as follows the judge deemed to know all the laws that the court may not refuse to investigate and adjudicate the case. This is confirmed in Article 10 of Act No. 48 of 2009 on Judicial Power, as follows ${ }^{15}$ :

(1) "The court banned refuse to examine, hear and decide a case filed on the grounds that the law does not exist or is less clear, but obliged to examine and hear;

\footnotetext{
${ }^{14}$ Sahrul Mauludi, 2018, Seri Cerdas Hukum : Awas Hoax!, PT. Elex Media Computindo, Jakarta, p. 334

${ }^{15}$ Act No. 48 of 2009 on Judicial Power
} 
Consideration of the judge in deciding the case in State Court of Blora No. 47 / PID. SUS / 2017 / PN.Blora ${ }^{16}$ According to Dwi Ananda Fajarwati, SH, MH, the judge decide the case according to the indictment from the prosecutor. In this case the prosecutor indicted in the indictment that Bambang Tri Mulyono Bin (Alm) Suradi Crime guilty of violating Article 28 paragraph (2) Jo. Article 45 A (2) Republic Act number 19 of 2016 on the amendment of Act No. 11 Of 2008 on Information and Electronic Transactions Jo. Article 64 paragraph (1) of the Criminal Law Act. Because of Article 193 paragraph (1) of Act No. 8 of 1981 on Criminal Proceedings ( "Criminal Code") states:

"If the court found the defendant guilty of committing a crime against her, the court will convict him"

A judge wrote in his book that the verdict of punishment (veroordeling) in Article 193 paragraph (1) of the Criminal Procedure Code can occur if: ${ }^{17}$

- From the results of the examination before trial;

- The judges found:

- defendant as charged in the indictment the prosecution has been proven legally and convincingly by law;

- The scope of the actions of the defendant constitute a criminal offense (misdrijven) or offense (overtredingen).

- Compliance with the provisions of the evidence and facts in the trial in accordance with Article 183 and 184 paragraph (1) Criminal Procedure Code.

Therefore, the judges then ruled on criminal prosecution to the defendant. Thus, references to the judges in deciding the case is a letter of indictment, not a summons. According to ${ }^{18} \mathrm{Rr}$. Endang Dewi Nugraheni, $\mathrm{SH}, \mathrm{MH}$, consideration of the judge in deciding the case has been in accordance with the charges of the prosecutor, other than that the case is done reporting on the basis of status facebook written by the defendant Bambang Tri Mulyono Bin (Alm) Suradi, with a facebook account Bambang Tri , Prosecutors indicted so the article is Article 28 paragraph (2) Jo. Article 45 A (2) of the Constitution of Republic of Indonesia number 19 Of 2016 on the amendment of Act No. 11 Of 2008 on Information and Electronic Transactions Jo. Article 64 paragraph (1) of the Criminal Justice Act.

\subsection{The Existence Of Article Insults President At Future Associated With Rising Of Social Media}

Both in conscious or not, of human life next few years are increasingly using technology and Act No. 11 of 2008 on Information and Electronic Transactions, have not been up to reach it. It is expected that in the future, insult the president is not equated with the usual contempt, as was stated in the Act No. 11 of 2008 on Information and Electronic Transactions today.

Constitutional law expert from the University of Parahyangan Asep Yusuf Warlan rate, the need for articles of insult against the president and vice president to ensnare

\footnotetext{
${ }^{16}$ Results Interview with Justice and Legal Panmud State Court of Blora, dated December 27, 2019

${ }^{17}$ Lilik Mulyadi. 2010, Seraut Wajah Putusan Hakim dalam Hukum Acara Pidana Indonesia: Perspektif, Teoritis, Praktik, Teknik Membuat dan Permasalahannya. Citra Aditya Bakti, Bandung, p.354

${ }^{18}$ Results Interview with Justice and Legal Panmud State Court of Blora, dated December 27, 2019
} 
offenders insulting state symbols. According to him, this article is necessary because the Law on Information and Electronic Transactions (ITE) does not reach beyond the perpetrators of defamation in the electronic media ${ }^{19}$, As in the case carried out by Bambang Tri Mulyono Bin (Alm) Suradi, because of limited law enforcement motion, eventually the charges toBthreshold Tri Mulyono Bin (Alm) Suradi, only centered on the humiliation in social media facebook under 11 of 2008 on Information and Electronic Transactions, whereas humiliation regulated in Act No. 11 of 2008 on Information and Electronic Transactions, does not distinguish between the outrages committed to the president or an insult to ordinary people.

Existence article insult the president in the future, should come up again and if it is associated with the rise of Social Media, insult the President in social media is quite simply inserted into the Criminal Code alone, all these rules, could reach the criminal insult the President by any form of media used. The government has handed article 786 of the Criminal Code Bill to Parliament, for approval into the Criminal Code. One article offered is that of the insult the president. Criminal Code draft version of the government submitted to parliament at 05 June 2015. According to Article 264 RKUHP draft, the result of the meeting between the Government and the Parliament by January 2018, a person who disseminates an insult to the president and vice president by means of information technology may be liable to imprisonment of 5 years. However disseminate content can not be categorized as an insult if conducted in the public interest. For the sake of truth and self-defense. This was confirmed in an effort to protect the freedom of expression in a democracy ${ }^{20}$.

Draft Penal Code as of August 2019, the offense of insult or defamation arranged in book II, chapter II of the offense to the dignity of the President and Vice President.

Article 218

(1) Any person who publicly attacked the honor or dignity of the self-President or VicePresident shall be punished with imprisonment of 3 (three) years and six (6) months or a maximum fine of Category IV.

(2) There is an assault honor or dignity of the referred to in paragraph (1) if the act is done in the public interest or self-defense.

In Chapter I of the Criminal Code already contains a bill on the extension on cybercrime, which are:

- Definition of "goods" in Article 152, which reads:

"Goods are tangible objects including water and demand deposits, and intangible, including electricity, gas, data and computer programs, services including telephone services, telecommunication services, or computer services"

This understanding is expressly recognizes that the object / intangible goods are goods / objects that can be used as evidence before the old Penal Code (Penal Code currently) the term is still a long debate legal experts.

- Definition of "space" in Article 181 which reads:

"Space is included stretch or computer terminal that can be accessed in certain

19 https://republika.co.id/berita/p3rpqa354/pengamat-uu-ite-saja-tak-cukup-jerat-penghina-presiden, Accessed on January 19, 2020, 20:00 pm

20 https://nasional.kompas.com/read/2018/01/31/13001421/dalam-rkuhp-menghina-presiden-lewatteknologi-informasi-bisa-dipidana.diakses on Sunday, January 5, 2020, 15:00 pm 
ways."

Understanding outlines that the locus delichti space (the scene of the law) does not just happen in a real space visible, but in cyberspace. In this case twitter been reachable by the Criminal Code draft

- Definition of "Letter" in Article 183

Letter is a document written on paper, including documents or data that is written or stored on disks, magnetic tapes, computer storage media or other electronic data storage media

- Definition of "electronic information" in Article 181, which reads

"Electronic information is one or a set of electronic data, including but not limited to text, sound, pictures, maps, plans, photographs, exchange data electronically (electronic data interchange), electronic mail, telegram, copying remotely (telecopy) or the like, letters, signs, numbers, access codes, symbols, or perforations that have been processed that has meaning or can be understood by people who are able to understand.

With the expansion of the definition in the book I above, the new penal code is expected to encompass the case of cybercrime while using the formulation of the offense contained in book II as offense-related insults. Obviously with the expansion of the definition of the offenses later handling is not only seen in the corner of a conventional offense act, but also can be applied or equated with crime offense today. By retaining the existence of article insult the president in RKUHP, and even fix it again. The theory of crime prevention implemented through repressive efforts in terms of punishment, with the rules governing. Because ius curia novit principle ${ }^{21}$ in which the judge deemed to know all the laws so that the Court may not refuse to investigate and adjudicate the case.

\section{Closing}

\subsection{Conclusion}

- The impact of the removal of article juridical criminal act of insult the president by the State Court Decision Number 013-022 / PUU-IV / 2006 when articles of insult against the President revoked / abolished, could damage the system in the inclusion of clauses concerning the overall humiliation act, addition evoke their legal vacuum in the crime of insult the president. While the conclusion of the Consideration State Court of Blora Judge in Decision No. 47 / Pid.Sus / 2017 / PN. Blora in deciding the case it is consistent with the indictment of the prosecutor.

- Existence article insult the president in the future, should come up again and if it is associated with the rise of social media, insult the president on social media is quite simply inserted into the Criminal Code alone, all these rules, could reach the criminal insult the president with any form of media used.

\subsection{Suggestion}

\footnotetext{
${ }^{21}$ M. Yahya Harahap. 2016. Hukum Acara Perdata tentang Gugatan, Persidangan, Penyitaan, Pembuktian dan Putusan Pengadilan. Sinar Grafika. Jakarta, p.821
} 
- Settings article of insult against the President is still needed in Indonesia. It is used to protect the dignity of the President as Head of State and Head of government

- Government or other state institutions should be more to educate teens began to actively use social media, to be positive and be wise in using social media news especially on hoax and others even dealing with defamation.

\section{References}

\section{Book}

[1] Adami Chazawi, 2016, Hukum Pidana Positif Penghinaan (Edisi Revisi), cet.2, Media Nusantara Creative, Malang;

[2] Department of Education, 1989, Kamus Besar Bahasa Indonesia, print.2 ${ }^{\text {nd }}$, Balai Pustaka, Jakarta;

[3] Eddy OS Hiariej, 2014, Prinsip-Prinsip Hukum Pidana, Cahaya Atma Pustaka, Yogyakarta;

[4] Ibn Taymiyyah, 2014, Sharimul Maslul : Hukuman Mati Bagi Penghina Nabi, Penerjemah Rohmatullah Ngimaduddin, Al Qowam, Solo.

[5] Irawan Santoso and Togi Simanjuntak, 1998, Politik Pembebasan Tapol, Yayasan Lembaga Bantuan Hukum Indonesia, Jakarta;

[6] Lilik Mulyadi. 2010, Seraut Wajah Putusan Hakim dalam Hukum Acara Pidana Indonesia: Perspektif, Teoritis, Praktik, Teknik Membuat dan Permasalahannya. Bandung: Citra Aditya Bakti;

[7] Mardjono Reksodiputro, 2009 Tentang Penghinaan Terhadap Presiden Dan Wakil presiden Serta Kebebasan Memperoleh Informasi, dalam Buku Menyelaraskan Pembaruan Hukum, Komisi Hukum Nasional, Jakarta;

[8] M. Yahya Harahap. 2016. Hukum Acara Perdata tentang Gugatan, Persidangan, Penyitaan, Pembuktian dan Putusan Pengadilan. Sinar Grafika. Jakarta;

[9] R. Susilo. 1991 Kitab Undang-Undang Hukum Pidana (KUHP) Serta KomentarKomentarnya Lengkap Article Demi Article , Politeia, Bogor;

[10] Sahrul Mauludi, 2018, Seri Cerdas Hukum : Awas Hoax!, PT. Elex Media Computindo, Jakarta;

[11] Wirjono prodjodikoro 2002, Tindak-Tindak Pidana Tertentu Di Indonesia, Refika Aditama, Bandung;

\section{Constitution}

[1] Act No. 48 of 2009 on Judicial Power;

[2] State Court Decision number: 013-022 / PUU-IV / 2006;

[3] State Court of Blora's Decision No. 47 / Pid. Sus / 2017 / PN.Bla;

[4] Act No. 11 of 2008 on Information and Electronic Transactions;

[5] Book of the Criminal Justice Act;

[6] Book of the Criminal Justice Act;

\section{Internet}

[1] https://handarsubhandi.blogspot.com/2015/08/upaya penanggulangan kejahatan (accessed on February 8th, 2020 at 21:05 pm) 
[2] http://pn-blora.go.id/main/index.php/berita/berita-terkini/937-vonis-3-tahunpenjara-untuk-penulis-buku-jokowi-undercover, Accessed Sunday, September 15, 2019 at 18:00 pm

[3] Hidayat Nur Wahid, Lembaga Negara Berdasarkan Undang - Undang Dasar Negara Republik Indonesia Tahun 1945, article, Legality 2006, taken fromhttp://www.legalitas.org/?q=node/75, accessed on 16 October 2019 at 16:00 pm

[4] https://republika.co.id/berita/p3rpqa354/pengamat-uu-ite-saja-tak-cukup-jeratpenghina-presiden, Accessed on January 19, 2020, 20:00 pm;

[5] https://nasional.kompas.com/read/2018/01/31/13001421/dalam-rkuhpmenghina-presiden-lewat-teknologi-informasi-bisa-dipidana. accessed on Sunday, January 5, 2020, 15:00 pm 